Indonesian Journal of Islamic Communication, Vol. 1, No. 1, Juni

\title{
PENDEKATAN DALAM STUDI ISLAM PEMBACAAN ATAS PIMIKIRAN CHARLES J. ADAMS
}

\author{
Naufal Cholili \\ Dosen Fakultas Ushuluddin UIN Sunan Ampel Surabaya
}

Diunggah 20 Juni 2018 / Direvisi 25 Juni 2018/ Diterima 29 Juni 2018

\begin{abstract}
Abstrac: Islam as a belief system has a religious element. The diversity in Islam must be comprehensively understood so as to be accepted by all circles, whether Muslim or non-Muslim. Understanding the religiousness of Islam should be viewed from its constituents, Islam and Religion. The form of the complete definition of the two, raises its own polemic for one of the figures in the religious study (religion wissenchaft), Chaerles J. Adams. In understanding the Religion, Adams uses the theoretical framework of Wilfred C. Smith that distinguishes between belief and tradition. While in the study of religious Islam, Adams proposed two approaches that are a series of unity (continuum), normativereligious approach and descriptive approach. Including a normative-religious approach is a traditional missionary approach, apologetic approach, and irenic approach. While descriptive approach is the approach of philology and history, approach to the social sciences, phenomenology approach. This approach is used to analyze the area of Islamic studies. Adams divides the area of Islamic studies into 11 subjects of study; Pre-Islamic Arabs, Mohammed, Qur'an, Hadith, kalam, law, philosophy, tasawwuf, the flow of Islam, the practice of worship and popular relegion (religious life). The appraisal initiated by Adams, has contributed to the improvement and development of religious studies. Adams's ideas are often referred to in several later Islamic studies
\end{abstract}

Keywords; Adams, Orientalisme, Studi Agama.

Korespondensi: Naufal Cholili

Gedung Fakultas Ushuluddin UIN Sunan Ampel Surabaya naufalcholili@yahoo.com 


\section{A. PENDAHULUAN}

Seiring dengan perkembangan keilmuan, Islam tidak lagi dipahami secara teologis sebagai sebuah doktrin keyakinan, akan tetapi Islam telah menjadi satu sistem budaya, peradaban dan bagian dari perkembangan sosial-kemasyarakatan. Hal ini menjadikan Islam berkembang tidak hanya sebagai satu perangkat keyakinan akan tetapi juga sebagai tradisi.

Islam sebagai sebuah sistem ajaran tentang ketuhanan, tidak dapat terlepaskan dari terma agama. Keduanya, memiliki keterkaitan karena mengandung beberapa unsur yang sama. Akan tetapi tidak dapat dikatakan bahwa keduanya adalah sama.

Munurut Charles J. Adams, Islam dan Agama merupakan dua kata kunci yang sulit dalam kajian tradisi keberagamaan Islam. Kesulitan tersebut terletak pada bagaimana memahami keduanya dalam bentuk pemahaman yang utuh yang dapat diterima oleh semua kalangan. Begitu juga, bagaimana menemukan konteks yang tepat dalam menggunakan kedua istilah tersebut. ${ }^{1}$

Untuk menjawab kegelisahan akademis tersebut, Adams memberikan beberapa definisi mengenai Islam dan Agama. Islam dalam pandangan Muslim secara umum adalah sebuah peradaban dan orientasi hidup. ${ }^{2}$ Hal ini mengandung pengertian bahwa seluruh tindakan manusia bersumber dari aturan-aturan Islam. Dengan pengertian ini, menurut Adams, tidak teridentifikasi sebuah pemahaman yang dapat membedakan antara pengalaman keislaman yang sifatnya religius dan yang tidak.

Menurut, Adams, perdebatan akan selalu muncul untuk memahami Islam secara komprehensif. Hal ini disebabkan sudut pandang yang digunakan sebagai pendekatan untuk menjelaskan tentang Islam. ${ }^{3}$ Bagi Adams, tidak ada harapan untuk mencapai satu definisi yang esensial tentang Islam yang diterima secara umum. Oleh sebab itu, Adam berpandangan bahwa Islam harus dipahami dalam perspektif historis sebagai sebagai sesuatu yang selalu berubah (change), berkembang dan terus

\footnotetext{
${ }^{1}$ Charles J. Adams, "Islamic Religious Tradition" dalam The Study of the Middle East; Reasearch and Scholarship in the Humanities and the Social Science, ed. Leonard Binder (Canada: John Wiley \& Sons, 1979), 29.

2 lbid.

${ }^{3}$ Ibid., 31.
} 
berkembang (evolve) dari generasi ke generasi dalam merespon secara mendalam realitas (vision of reality) dan makna kehidupan manusia (meaning of human life). ${ }^{4}$

Dengan pengertian ini, Adams memberikan gambaran bahwa Islam bukan hanya terdiri dari satu hal akan tetapi terdiri dari banyak hal. Begitu juga, Islam bukan lagi sistem kepercayaan, ibadah ataupun semacamnya, akan tetapi Islam adalah sebuah sistem yang komplek (many systems) dalam bingkai sejarah yang selalu berubah dan berkembang. ${ }^{5}$ Perubahan tersebut, menurut Adams, dalam hal pengalaman (experience) dan ekspresi yang berdiri di atas perkembangan sejarah berdasarkan wahyu (massage) dan pengaruh Nabi.

Perubahan ini dapat diasumsikan bahwa Islam tidak hanya berdiam dalam sakralitasnya, akan tetapi Islam dalam perkembangannya menampilkan sifat profannya yang justru menjadikan Islam lebih dekat dengan penganutnya. Tampilan semacam ini, oleh Amin Abdullah disebut dengan multifaces. Sehingga Islam tidak hanya single face akan tetapi multifaces yang tidak lagi dipahami semata-mata terkait dengan persoalan ketuhanan, kepercayaan, keimanan, credo, pedoman hidup, dan ultimate concern, akan tetapi juga terkait dengan persoalan historis-kultural. ${ }^{6}$

Dalam memahami Agama, menurut Adams, sama sulitnya dengan memahami Islam. Hal ini terbukti jelas dengan adanya usaha bagi para sarjana untuk memberikan gambaran tentang Agama. Mereka memahami Agama sebagai respon manusia terhadap kekuatan yang besar dan tak terkendali dari Alam, seperti ketakutan dan jaminan keamanan. Bagi Adams, eksplorasi tentang pemahaman tentang Agama dari sesuatu yang termanifestasi dan yang tersembunyi merupakan tugas dari para pengkaji Agama. Untuk mengatasi problem pemahaman terhadap Agama, Adams menggunakan kerangka pemikiran Wilfred C. Smith. Smith sebagaimana dikutip Adams, membedakan antara tradisi (tradition) dan kepercayaan (faith). ${ }^{7}$ Smith membedakan agama menjadi dua bagian utama, tradisi dan kepercayaan dengan observasi secara historis. Bagi Smith, untuk mendefinisikan tradisi adalah yang mudah. Tradisi adalah sebuah doktrin, aturan-aturan atau apapun yang dapat diwariskan dari generasi ke generasi yang dapat diamati dan bernilai

\footnotetext{
${ }^{4} \mathrm{lbid}$.

${ }^{5}$ lbid.

${ }^{6}$ Amin Abdullah, dkk, Mencari Islam: Studi Islam dengan Berbagai Pendekatan (Yogyakarta: Tiara Wacana Yogya, 2000), 2.

${ }^{7}$ Adams, "Islamic Religious Tradition", 33.
} 
objektif. ${ }^{8}$ Sedangkan kepercayaan bagi Smith adalah esensi dari sebuah tradisi. ${ }^{9}$ Hal ini dapat berarti bahwa kepercayaan adalah kualitas yang menjadikan sesorang dikatakan beragama (religious). Hal ini juga menjadikan kepercayaan adalah aspek internal dalam agama yang tidak terdefinisikan. ${ }^{10}$

Menurut Adams, pemikiran Smith mengindikasikan bahwa Agama beridiri di dua kutub yang berbeda. Di sisi ekternal, dibutuhkan pengamatan secara sosial dan historis. Dan di sisi lain, yakni internal, agama tidak dapat terdefinisikan (ineffable), orientasi transendental dan dimensi pribadi mengenai pengalaman keagamaan. ${ }^{11}$

Dalam mengkaji pendekatan studi Islam, Adams bukanlah orang pertama yang memfokuskan pada kajian tersebut. Kajian-kajian lain sebelum Adams banyak bermunculan yang juga menjadi bagian dari kerangka teori yang digunakannya dalam melakukan pendekatan kajian Islam. Diantaranya, Wilfred Cantwell Smith, beberapa karya Smith yang dikutip oleh Adams, Modern Islam in India, Islam in Modern History, The Meaning and End of Religion dan Religious Diversity and Modernity. Begitu juga Gustav Edmund von Grunebaum, dengan karyanya, Muhammadan Festivals, Medival Islam: a Study in Culture Orientation, atau Studies in Islamic Cultural History. Dan Kenneth Cragg dengan karyanya, The Event of The Qur'an, The House of Islam, Counsels in Contemporary Islam.

\section{B. PEMBAHASAN}

\section{Kerangka Pendekatan dalam Studi Islam}

Untuk memberikan gambaran penyelesaian akan kegelisahan akademiknya, Adams menawarkan beberapa pendekatan yang digunakan dalam mengakaji Islam yang memiliki 11 bidang pokok. Pendekatan ini juga merupakan metode yang digunakan Adams untuk memahami Islam. Penjelasan mengenai metode dan konsep dasar yang ditempuh oleh Adams dipaparkan melalui penjelasan berikut:

1. Pendekatan Normatif atau Keagamaan, pendekatan ini terdiri dari:

a. Pendekatan Misionaris Tradisional

Pada abad ke-19, terjadi peningkatan aktivitas misionaris yang dilakukan oleh gereja-gereja, aliran dan golongan umat beragama. Hal ini

\footnotetext{
${ }^{8}$ Wilfred Cantwell Smith, Religious and Modernity (New York: The Crossroad, 1982), 104.

${ }^{9}$ lbid.

${ }^{10}$ Adams, "Islamic Religious Tradition", 33.

${ }^{11}$ Ibid.
} 
sejalan dengan pertumbuhan politik, ekonomi dan militer di eropa. Aktivitas misionaris ini memiliki pengaruh di beberapa bagian di kawasan Asia dan Afrika. Sebagai konskuensi dari peningkatan aktivitas ini, sejumlah individu mendedikasikan diri mereka untuk melakukan perjalanan ke Asia dan Afrika sebagai bagian dari kolonial untuk mengkristenkan masyarakat dan merubah pandangan terhadap peradaban barat. ${ }^{12}$

Seperti halnya para kolonial, misonaris mempelajari bahasa dan berpartisipasi dalam kegiatan masyarakat yang sifatnya kultural demi efektitas tujuan mereka. Konsekuensinya, beberapa misonaris menguasai bahasa yang digunakan umat Islam secara baik dan melakukan penelitian terhadap budaya Islam secara mendalam. Pengetahuan tentang ke-Islaman yang mendalam, membantu mereka menciptakan pendekatan terhadap umat Islam dan membantu mereka terlibat dalam penyelesaian masalah konflik keagamaan.

Upaya kristenisasi mereka ditempuh dengan cara membandingkan antara keyakinan Islam dan keyakinan kristen yang selalu merugikan Islam. Meskipun demikian, menurut Adams, para misonaris memiliki kontribusi besar dalam pertumbuhan keilmuan Islam hingga kini. Meskipun tidak sepakat dengan tujuan mereka, Kontribusi yang mereka berikan tidak boleh diabaikan karena semua orang yang mempelajari kajian ke-Islaman berhutang banyak kepada mereka. ${ }^{13}$

b. Pendekatan Apologetik

Karakter pokok dari Muslim di abad ke-20 adalah kesenangan mereka terhadap pembelaan terhadap keyakinan atau pendirian (apologetik). Menurut Adams, sikap apologetik adalah respon dari mentalitas seorang Muslim terhadap situasi modern yang dihadapi umat Islam. Selain itu, adanya kesadaran dari umat Islam untuk membangkitkan kembali dari keterpurukan dan sebagai upaya tandingan dari serangan gangguan barat. Kesadaran akan keterpurukan tersebut, umat islam berusaha untuk memulihkan kembali nilai-nilai dasar dari tradisi. Dan hal

12 Ibid., 35.

13 Ibid. 
inilah yang memunculkan usaha untuk memodernisasi diri dimana hal ini dianggap kunci untuk memperoleh kembali kekuatan dan keagungan yang telah hilang. Sehingga dengan model apologetik dapat membawa Islam ke era baru yang cemerlang. ${ }^{14}$

Tema-tema yang dijadikan fokus para pengakaji dengan pendekatan apologetik, merupakan tema-tema yang familiar bagi para sarjana Islam, seperti tuntutan penggunaan rasio dalam Islam, kesesuaian dengan sains, semangat kemajuan, pandangan kebebasan etika, keuntungan untuk manusia. Beberapa orang yang tertarik dengan tema tersebut adalah Sayyid Amir Ali dengan karyanya The Spirit of Islam, W.C. Smith dengan bukunya Modern Islam in India dan Islam in Modern History. ${ }^{15}$

Dalam analisa Adams, hal terpenting yang dihasilkan para pengkaji dengan pendekatan apologetik adalah kebangkitan akan identitas baru bagi generasi muda muslim dan menciptakan kebanggaan terhadap warisan tradisi. Begitu juga, bagi Adams, peran apologetist menghasilkan banyak penemuan kembali berbagai aspek dibidang sejarah Islam dan capaian yang telah banyak dilupakan oleh umat Islam. Dan hasilnya berupa banyaknya kegiatan penelitian dan penulisan yang telah memperkuat pengetahuan umat Islam tentang warisan agama, intelektual, dan kultur mereka sendiri. ${ }^{16}$

Akan tetapi, menurut Adams, para tokoh apologetik sering terjebak dalam kesalahan karena terlalu fokus untuk menampilkan Islam dengan hal yang menguntungkan sehingga banyak melemahkan nilai-nilai ilmiah. Pendekatan apologetik sering mengahsilakan literatur yang mengandung banyak kesalahan dalam bentuk distorsi, selektif dan berlebihan dalam penggunaan bukti, menampilkan romantisisme sejarah dan pencapaian-pencapaian umat Islam, membuat kesalahan dalam melakukan analisa perbandingan. Dan kesalahan yang paling fatal menurut Adams adalah memperlihatkan karakter tendensiusnya. Kesalahan mendasar yang dilakukan para apologetik adalah motivasi mereka dalam

\footnotetext{
14 Ibid., 37.

15 Ibid.

16 Ibid.
} 
melakukan kajian yang dimotivasi oleh keinginan mempertahankan diri bukan tujuan ilmiah. ${ }^{17}$

Pendakatan semacam ini, menurut Amin Abdullah banyak digunakan dalam kajian keislaman di perguruan tinggi Islam di Indonesia. Dominasi misi keagamaan yang bersifat memihak, romantis dan apologis menjadikan wilayah analisis yang sifatnya kritis, metodis dan historisempiris kurang menonjol. ${ }^{18}$ Sehingga menjadikan wilayah dan ruang kajiannya menjadi terdistorsi.

c. Pendekatan Irenic (secara damai)

Sejak perang dunia II telah berkembang gerakan yang berbeda di barat yang diwakili oleh kelompok agama dan universitas. Tujuan mereka adalah memberikan apresiasi yang besar keberagamaan Islam dan memelihara sikap terhadap Islam. Pendekatan ini juga memiliki hubungan dengan pendekatan missionaris yang telah dilakukan. Sehingga pendekatan ini sebagai upaya untuk menghilangkan kecurigaan, permusuhan, dan merendahkan tradisi Islam. Pada saat yang sama, dilakukan dealektika dengan umat Islam dengan harapan dapat terbangun jembatan penghubung bagi terwujudnya saling simpati antara tradisi keagamaan dengan negara.

Salah satu tokoh dalam pendekatan ini adalah Kenneth Cragg. Menurut Adams, selama empat tahun, Cragg mencoba menjalin hubungan dengan umat Islam yang terpelajar dan para tokoh demi menghasilkan tingkat kesesuain yang lebih besar antara umat Islam dengan Kristen. Cragg berusaha menampilkan kepada masyarakat Barat dan Kristen beberapa bagian keindahan dan nilai keagamaan yang menjiwai tradisi Islam. Dan bagi Cragg sebagaiman dikutip Adams, dengan dasar nilai-nilai tersebut, umat Kristen memiliki tugas untuk terbuka dan menerima hal tersebut. Kemudian Cragg memulai dengan mendomonstrasikan bahwa umat Islam concern dengan problematika dan isu yang sama yang sifatnya fundamental bagi umat Kristen, meskipun dengan menggunakan istilah

\footnotetext{
17 Ibid.

${ }^{18}$ M. Amin Abdullah, Studi Agama: Normativitas atau Historisitas (Yogyakarta: Pustaka Pelajar, 1996), 106.
} 
yang berbeda dan dipandu oleh kesadaran yang berbeda akan prioritas dalam gagasan mereka mengenai wawasan keagamaan. ${ }^{19}$

Contoh lain pendekatan irenic diterapkan oleh W.C. Smith, dalam karyanya The Faith of Other Men dan artikelnya berjudul Comparative Religion, Whither and Why?. Hal utama yang ditampilkan dalam tulisan Smith adalah memahami keyakinan orang lain dan bukan untuk mentransformasikan keyakinan itu atau dengan motif penyebaran agama. ${ }^{20}$ Smith menganggap bahwa suatu pernyataan mengenai suatu agama, yang dikemukakan oleh seseorang yang tidak memeluk agama, dapat dianggap valid, maka pernyataan tersebut harus dapat diterima tidak saja oleh sarjana-sarjana di luar lingkungan pemeluk agama yang dimaksud, melainkan dianggap valid dan benar oleh mereka yang memeluk agama tersebut. ${ }^{21}$

Selain kedua tokoh tersebut, Adams juga menyebut Montgomery Watt, dan Geoffrey Parrinder. Meskipun kedua tokoh tersebut oleh Adams tidak dijelaskan pemikirinnya secara mendetail.

2. Pendekatan Deskriptif

Dalam pendekatan ini, Adams membagi menjadi tiga, yakni:

a. Pendekatan Filologi dan Sejarah

Menurut Adams, sudut pandang dalam kajian Islam yang paling produktif adalah filologi dan sejarah. Lebih dari 100 tahun sarjana barat membekali diri dengan prinsip-prinsip bahasa orang Islam dan dilatih dalam penggunaan metode filologi untuk memahami teks-teks yang menjadi bagian dari warisan keagamaan Islam. Karya di bidang filologi, sebenarnya merupakan hasil dari kajian perbandingan bahasa semit atau studi terhadap Bibel. ${ }^{22}$

Bahasa Semit menggunakan bahasa Arab yang paling dikenal secara luas dan paling lama penggunaannya dalam kehidupan sehari-hari.

\footnotetext{
${ }^{19}$ Adams, "Islamic Religious Tradition", 37.

20 Ibid., 40.

${ }^{21}$ Lihat Wilfred Cantwell Smith, "Comparative Religion, Whither and Why?" dalam Religious Diversity, ed. William K. Oxtoby (New York: Crossroad, 1982), 154.

22 Adams, "Islamic Religious Tradition", 41.
} 
Oleh sebab itu, bahasa Arab seringkali menjadi kunci bagi non-Arab untuk memahami tradisi linguistik Semit.

Pendekatan filologi dapat digunakan hampir dalam semua aspek kehidupan umat Islam. Kajian filologi tidak hanya digunakan untuk kepentingan orang Barat dalam mengkaji Islam dan sejarahnya, akan tetapi juga memainkan peran penting dalam dunia Islam. Melalui pendekatan filologi dan sejarah, para sarjana telah menemukan kembali masa kejayaan budaya Islam yang terlupakan di kalangan Muslim, padahal ia menjadi salah satu faktor penentu pada masa sekarang ini untuk melakukan revitalisasi Islam.

Menurut Adams, filologi memiliki peran vital dan harus tetap dipertahankan untuk memainkan perannya dalam kajian Islam. Hal ini disebabkan oleh banyaknya dokumen-dokumen masa lampau dalam bidang sejarah, teologi, hukum, tasawuf dan lain sebagainya, yang belum terekploitasi oleh para sarjana barat karena belum banyak yang diterjemahkan ke dalam bahasa Eropa. ${ }^{23}$

Metode filologi dan sejarah akan tetap relevan untuk studi Islam, baik untuk masa lalu, sekarang maupun yang akan datang. Adams lebih lanjut menjelaskan, penekanan terhadap pendekatan filologi ini bukan berarti tidak menghargai pendekatan lain untuk mengkaji kehidupan umat Islam kontemporer. Pendekatan behavioral (ilmu-ilmu sosial) kontemporer terhadap Islam tetap memiliki signifikansi dalam membangun pengetahuan tentang Islam sebagai sebuah living religion. Yang hendak ditegaskan Adams adalah filologi merupakan kata kunci untuk melakukan penelitian tentang realitas praktek dan kelembagaan Islam di masa lalu. Metode dan pendekatan ilmu-ilmu sosial harus digunakan apabila cocok digunakan tetapi tidak harus menolak tradisi penelitian filologi. ${ }^{24}$

Relasi filologi dengan ilmu-ulmu sosial yang dibahas Adams, dapat ditemukan korelasinya dalam pemikiran Ernest Renan. Ia berhasil

\footnotetext{
$23 \mathrm{lbid}$.

24 Ibid., 43.
} 
menempatkan dirinya sebagai filolog yang memiliki relasi dengan masalah-masalah sosial yang cukup krusial pada masanya (1848). ${ }^{25}$

Pendekatan Filologi dan sejarah yang digagas Adams, lebih mirip dengan pendekatan yang digunakan Renan. Renan mencoba untuk mengkorelasikan secara jelas antara folologi dan sejarah. Dalam salah satu ceramahnya di Sobonne dengan judul "Tentang Pengabdian Filologi kepada Ilmu-ilmu Sejarah", yang dikutip Said, dijelaskan bahwa apa yang diajarkan filologi sama halnya dengan apa yang diajarkan agama mengenai asal-usul manusia, peradapan dan bahasa. ${ }^{26}$

b. Pendekatan ilmu-ilmu sosial

Perkembangan yang sangat penting pada abad ini adalah lahirnya ilmu sosial yang mewarnai dan meramaikan kehidupan akademik dan intelektual. Dengan berbagai alasan yang berbeda, para ilmuwan sosial telah tertarik terhadap Timur Tengah, terutama melakukan pengkajian tentang Islam. Di Amerika Utara, banyak karya hasil tulisan yang mengkaji tentang tradisi keagamaan Islam secara kuantitatif yang justru bukan dihasilkan oleh ilmuan berbasis humanitis atau seseorang yang yang mempunyai latar belakang pendidikan studi agama, akan tetapi dilakukan oleh para ilmuwan sosial. Karya ilmuwan sosial tersebut dapat meningkatkan pemahaman para peneliti yang mengambil area studi Timur Tengah, karena metode yang digunakan pakar ilmu sosial dapat dijadikan alat analisis untuk memperluas pemahaman. ${ }^{27}$

Untuk menemukan ciri-ciri dari pendekatan ilmu-ilmu sosial untuk studi Islam sangatlah sulit, selagi terdapat beragamnya pendapat di kalangan ilmuwan sosial tentang validitas kajian yang mereka lakukan. Salah satu ciri utama pendekatan ilmu-ilmu sosial adalah pemberian definisi yang tepat tentang wilayah kajian mereka. Pendekatan dan pendirian yang mereka adopsi menghasilkan dinamika perubahan yang terus menerus dan menghasilkan kemajuan.

25 Edward W. Said, Orientalisme: Menggugat Hegemoni Barat dan Menundukkan Timur sebagai Subjek, terj. Ahmad Fawaid (Yogyakarta: Pustaka Pelajar, 2010), 202.

26 Ibid., 205.

27 Ibid., 44. 
Akan tetapi bagi Adams, jika muncul pertanyaan apakah sejarah bisa dianggap bagian dari ilmu sosial?. Maka Adams berpendapat bahwa studi sejarah bukanlah ilmu sosial. Perbedaan mendasar keduanya adalah sosiologi membatasi fokus studi pada aktivitas manusia, kemudian mencari metode khusus yang sesuai dengan obyek tersebut. Sedangkan sejarah memiliki tujuan lebih luas dan menggunakan metode yang berbeda. $^{28}$

Salah satu asumsi ilmuwan sosial adalah perilaku manusia yang mengikuti teori kemungkinan (possibility) dan obyektivitas. Bila perilaku manusia dapat didefinisikan dan diberlakukan sebagai entitas obyektif, maka akan dapat diamati dengan menggunakan metode empiris dan juga dapat dikuantifikasikan. Dengan pendekatan seperti itu, ilmuwan sosial menggambarkan agama dalam kerangka obyektif, sehingga agama dapat dijelaskan dan peran agama dalam kehidupan masyarakat dapat dipahami. ${ }^{29}$

Penelitian dalam ilmu sosial bertujuan untuk menemukan aspek empiris dari keberagamaan. Pandangan semacam ini dinilai Adams terlalu berbahaya karena akan menghasilkan deskripsi yang reduksionis terhadap keberagamaan seseorang. Dengan menggunakan pendekatan ilmu-ilmu sosial, maka agama akan dijelaskan dengan beberapa teori, misalnya agama merupakan perluasan dari nilai-nilai sosial, agama adalah mekanisme integrasi sosial, agama itu berhubungan dengan sesuatu yang tidak diketahui dan tidak terkontrol, dan masih banyak lagi teori lainnya. Bagi Adams, pendekatan ilmu-ilmu sosial hanya menjelaskan aspek empiris orang beragama sebagai pengaruh dari norma sosial, dorongan instinktif untuk stabilitas sosial, dan sebagai bentuk ketidakberdayaan manusia dalam menghadapi ketakutan. ${ }^{30}$

Karakteristik lain dari pendekatan ilmu-ilmu sosial adalah kecenderungan mengkaji manusia dengan cara membagi aktivitas manusia ke dalam bagian-bagian atau variabel yang berlainan. Akibatnya, seperti

\footnotetext{
28 Ibid.

${ }^{29}$ Ibid., 45.

${ }^{30} \mathrm{Ibid}$.
} 
yang dapat dilihat, terdapat ilmuwan sosial yang mencurahkan perhatian studinya pada perilaku politik, interaksi sosial dan organisasi sosial, perilaku ekonomi, dan lain sebagainya. Sebagai akibat lebih lanjut dari kelemahan ini, muncul dan dikembangkan metode masing-masing bidang atau aspek, kemudian berdirilah fakultas dan jurusan ilmu-ilmu sosial di beberapa universitas. Fakta tersebut membuktikan bahwa telah terjadi fragmentasi pendekatan dan terkotaknya konsepsi tentang manusia. ${ }^{31}$

Fragmentasi dalam kajian ilmu sosial terhadap Agama bertujuan untuk menemukan signifikansi Agama dalam dunia sosial. Oleh sebab itu, ditetapkan serangkaian kategori-kategori sosiologis yang menampakkan adanya fregmentasi tersebut. Semisal mengenai stratifikasi sosial yang membagi manusia dalam kelas dan etnisitas; kategori bisiososial seperti seks, gender, perkawinan, keluarga dan usia; pola organisasi sosial meliputi politik, ekonomi dan sistem birokrasi; proses sosial, seperti faormasi batas, relasi intergroup, dan interaksi personal. ${ }^{32}$

Menurut Adams pengecualian harus diberikan untuk pendekatan antropologi. Dalam banyak hal, pendekatan antropologi dan sejarah agama sangat erat. Hal ini disebabkan karena kedua disiplin ini sama-sama tertarik untuk mengkaji seluruh kehidupan masyarakat, antropolog melebihi ilmuwan politik, sosiologi atau ekonomi karena antropolog mengkaji seluruh aspek kehidupan masyarakat beragama yang dijadikan subyek studi. Pendekatan antropologi tertarik untuk mengkaji fenomena agama dan seluruh aspek ekspresi keberagamaan. Di antara ilmuwan sosial yang melakukan kajian Islam dengan pendekatan antropologi adalah Clifford Geertz. Pendekatan antropologi mampu menghasilkan studi yang menjelaskan tentang ekspresi keberagamaan Islam lokal menurut tempat dan gaya hidup yang berlainan. ${ }^{33}$

Pengecualian Adams, terhadap pendekatan Antropologis dengan menyebutkan Geertz, dapat diasumsikan kecendrungan Adams terhadap

\footnotetext{
31 Ibid., 46-47.

32 Michael S. Northcott, "Pendekatan Sosiologis", dalam Aneka Pendekatan Studi Agama, ed. Petter Connolly, terj. Ninian Smart (Yogyakarta: LkiS, 2002), 283.

33 Adams, "Islamic Religious Tradition", 48.
} 
aliran interpretivist ${ }^{34}$ dalam kajian antropologi. Geertz melepaskan diri dari belenggu fungsionalisme struktural yang dianut para antropolog sebelumnya. ${ }^{35}$ Geertz memandang bahwa kebudayaan adalah interpretasi tentang pengalaman dan tindakan manusia. ${ }^{36}$

Seorang ilmuwan sosial yang tetap mempertahankan model studi dengan memilih dan mengkotakkan aktivitas manusia ke dalam bentuk bagian-bagian, sebagai sudut pandang secara sempit tetapi masih sangat penting adalah pendekatan yang dilakukan oleh C.A.O. van Nieuwenhuijze dalam sebuah tulisannya "The Next Phase of Islamic Studies: Sociology?". Van Nieuwenhuijze menyatakan bahwa metode sosiologi dan ilmu sosial lainnya mungkin akan menambah pemahaman baru tentang tradisi keberagamaan Islam.

c. Pendekatan fenomenologi

Di samping melalui pendekatan yang telah disebutkan, seseorang dapat mencurahkan waktu dan energi untuk studi Islam dengan pendekatan atau dalam bentuk Religionswissenschaft (studi agama). Mereka yang menggunakan pendekatan ini secara formal memperoleh pendidikan tradisi Eropa dalam studi agama yang lahir dalam seperempat akhir abad ke-19, dan mereka yang berjuang keras menggunakan pendekatan ilmiah terhadap agama sebagai sebuah fenomena sejarah yang universal dan sangat penting. Di Amerika Utara pendekatan studi seperti ini dikenal dengan sebutan sejarah agama atau perbandingan agama.

Adams dalam tulisan ini mengabaikan bagaimana perubahan konsepsi Religionswissenschaft seperti pada awal kemunculannya kemudian menjadi fenomenologi sebagai salah satu ciri pendekatan dalam studi agama. Diakui Adams sangat sulit mendefinisikan fenomenologi agama, karena memang mereka sendiri yang menyebut fenomenologi agama. Ada dua hal yang menjadi karakteristik pendekatan fenomenologi. Pertama, bisa dikatakan bahwa fenomenologi merupakan metode untuk memahami agama orang lain dalam perspektif netralitas, dan

\footnotetext{
${ }^{34}$ Aliran ini memandang bahwa keteraturan sosial muncul dari berbagai perbuatan individu dari pada sebagai fakta kehidupan yang menentukan perbuatan individu (fungsionalisme struktural).

35 David N. Gellner, "Pendekatan Antropologis" dalam Aneka Pendekatan Studi Agama, 31-32.

${ }^{36}$ Abdullah, Mencari Islam, 142.
} 
menggunakan preferensi orang yang bersangkutan untuk mencoba melakukan rekonstruksi dalam dan menurut pengalaman orang lain tersebut. Dengan kata lain semacam tindakan menanggalkan diri sendiri (epoche), dia berusaha menghidupkan pengalaman orang lain, berdiri dan menggunakan pandangan orang lain tersebut. ${ }^{37}$

Epoche adalah salah satu bentuk metode yang digunakan oleh Edmund Husserl. Meskipun Husserl tidak secara langsung membahas studi agama, dua konsep yang mendasari karyanya (epoche dan eiditic) menjadi titik tolak metodologis yang bernilai bagi studi fenomenologis terhadap agama. Dalam kerangka Husserl, epoche membawa seseorang untuk mengendalikan prasangka atau worldview yang akan mepengaruhi hasil pemahaman. Sedangkan eiditic terkait dengan kemampuan melihat apa yang ada sesungguhnya. Eiditic mengendalikan epoche, ia memberi kemampuan melihat esensi fenomena secara objektif. ${ }^{38}$ Oleh sebab itu, dalam aspek pertama ini, seseorang yang melakukan kajian terhadap Islam, harus melepaskan diri dari semua pengetahuan yang dimiliki agar memperoleh hasil yang objektif.

Aspek ini, sangatlah fundamental dalam studi Islam. Ia merupakan kunci untuk menghilangkan sikap tidak simpatik, marah dan benci atau pendekatan yang penuh kepentingan (interested approaches) dan fenomenologi telah membuka pintu penetrasi dari pengalaman keberagamaan Islam baik dalam skala yang lebih luas atau yang lebih baik. Kontribusi terbesar dari fenomenologi adalah adanya norma yang digunakan dalam studi agama adalah menurut pengalaman dari pemeluk agama itu sendiri. ${ }^{39}$

Fenomenologi bersumpah meninggalkan selama-lamanya semua bentuk penjelasan yang bersifat reduksionis mengenai agama dalam terminologi lain atau segala pemberlakuan kategori yang dilukiskan dari sumber di luar pengalaman seseorang yang akan dikaji. Hal yang terpenting dari pendekatan fenomenologi agama adalah apa yang dialami

\footnotetext{
37 Adams, "Islamic Religious Tradition", 49-50.

38 Clive Erricker, "Pendekatan Fenomenologis", dalam Aneka Pendekatan Studi Agama, 111.

${ }^{39}$ Adams, "Islamic Religious Tradition", 49-50.
} 
oleh pemeluk agama, apa yang dirasakan, diakatakan dan dikerjakan serta bagaimana pula pengalaman tersebut bermakna baginya. Kebenaran studi fenomenologi adalah penjelasan tentang makna upacara, ritual, seremonial, doktrin, atau relasi sosial bagi dan dalam keberagamaan pelaku. ${ }^{40}$

Pendekatan fenomenologi juga menggunakan bantuan disiplin lain untuk menggali data, seperti sejarah, filologi, arkeologi, studi sastra, psikologi, sosiologi, antropologi dan sebagainya. Pengumpulan data dan deskripsi tentang fenomena agama harus dilanjutkan dengan interpretasi data dengan melakukan investigasi, dalam pengertian melihat dengan tajam struktur dan hubungan antar data sekaitan dengan kesadaran masyarakat atau individu yang menjadi obyek kajian. Idealnya, bagi seorang fenomenologi agama yang mengkaji Islam harus dapat menjawab pertanyaan: apakah umat Islam dapat menerima sebagai kebenaraan tentang apa yang digambarkan oleh fenomenologis sebagaimana mereka meyakini agamanya? Apabila pertanyaan ini tidak dapat terjawab, maka apa yang dihasilkan melalui studinya bukanlah gambaran tentang keyakinan Islam. ${ }^{41}$ Dalam hal ini, Adams menguatkan apa yang dikatakan W.C. Smith yang menyarankan bahwa pernyataan tentang sebuah agama oleh peneliti dari luar (outsider) harus benar, jika pemeluk agama tersebut mengatakan "ya" terhadap deskripsi tersebut. ${ }^{42}$

Aspek Kedua dari pendekatan fenomenologi adalah mengkonstruksi rancangan taksonomi untuk mengklasifikasikan fenomena masyarakat beragama, budaya, dan bahkan epoche. Tugas fenomenologis setelah mengumpulkan data sebanyak mungkin adalah mencari kategori yang akan menampakkan kesamaan bagi kelompok tersebut. Aktivitas ini pada intinya adalah mencari struktur dalam pengalaman beragama untuk prinsip-prinsip yang lebih luas yang nampak dalam membentuk keberagamaan manusia secara menyeluruh. ${ }^{43}$

\footnotetext{
40 Ibid.

${ }^{41}$ Ibid., 50-51.

42 Fazlur Rahman, "Approaches to Islam in Religious Studies" dalam approaches to Islam in Religious Studies, ed. Richard C. Martin (USA: Arizona State University, 1985), 190.

${ }^{43}$ Adams, "Islamic Religious Tradition", 51.
} 
Pendekatan fenomenologi menjadi populer di Amerika Utara dalam beberapa tahun terakhir ini karena pengaruh Mircea Eliade dan murid-muridnya, namun hampir tidak ada upaya untuk mengaplikasikan metode dan pendekatan ini untuk mengkaji Islam. Sebagai bahan perbandingan dari dua pendekatan Adams, penulis menampilkan pendekatan yang dilakukan Mircea Eliade yang dikutip oleh Clive Erricker. Meskipun secara tidak langsung Eliade menyebutkan pendekatannya dalam kajian agama, akan tetapi terdapat beberapa pendekatannya yang dapat dijadikan sebuah alternatif dalam pendekatan fenomenologis.

Eliade mengklasifikasikan pengalaman manusia terhadap sacred dan profane. Ia menyatakan bahwa dalam dunia modern, seseorang telah kehilangan pemahaman atas yang sakral dimana kebudayaan manusia sebelumnya telah memasukkannya ke dalam tuntunan hidup (the way of life). Deskralisasi (profane) ini kemudian menjadikan manusia kehilangan sifat religiuitasnya. ${ }^{44}$.

\section{Kontribusi pemikiran Adams terhadap pengetahuan}

Dengan meminjam istilah Mircea Eliade, Islam tidak hanya bisa dipahami sekedar dalam bentuk sacred-nya (sakralitasnya) akan tetapi pemahaman Islam perlu dilanjutakan ke sisi profane-nya (membumi). Hal ini bertujuan agar pemahaman tentang Islam lebih masuk dalam realitas sosial yang dihadapi oleh umat Islam.

Untuk mencapai tujuan ini maka diperlukan sebuah pendekatan baru agar umat Islam tidak hanya terpaku pada model pendekatan teologis-normatif ${ }^{45}$ yang menjadikan pemahaman tentang ke-Islaman menjadi stagnan. Oleh sebab itu, diperlukan keterbukaan pandangan untuk memahami Islam dengan pendekatan lain yang secara konseptual dapat memberikan wawasan yang luas tentang pemahaman terhadap Islam.

Salah satu tokoh yang memberikan perhatiannya terhadap studi keIslaman adalah Charles J. Adams. Berbagai pendekatan, yang baginya masih

\footnotetext{
44 Erricker, "Pendekatan Fenomenologis", 122.

45 Pendekatan teologis-normatif yang dimaksud adalah usaha dalam memahami agama dengan menggunakan kerangka ilmu keagamaan yang dianggap sebagai keyakinan yang paling benar. Pendekatan ini menekankan pada bentuk forma atau simbol-simbol keagamaan yang masing-masing mengklaim dirinya sebagai yang paling benar. Lihat Abuddin Nata, Metodologi Studi Islam (Jakarta: Rajawali Press, 2013), 28-29.
} 
terbuka untuk didiskusikan, memberikan sumbangsih besar terhadap perkembangan keilmuan khususnya dalam studi Agama.

Kontribusi besar dari pemikiran Adams adalah memberikan jarak terpisah antara pendekatan normatif yang memiliki komitmen religious dalam melakukan penelitian menuju pendekatan deskriptif yang tidak memiliki komitmen keagamaan. Meskipun keduanya merupakan rangkaian kesatuan. ${ }^{46}$ Pemisahan kedua pendekatan ini, memberikan kontribusi pada kerangka analitis untuk memisahkan dimensi sakral dan profan yang masih tumpang tindih.

Tumpang tindih antara yang sakral dan yang profan, menurut Amin Abdullah adalah bagian dari diskursus keagamaan kontemporer yang rumit untuk dipecahkan. ${ }^{47}$ Menurutnya, dari studi historis-empiris terhadap fenomena agama diperoleh masukan bahwa agama sesungguhnya juga sarat dengan berbagai kepentingan yang menempel dalam ajaran dan batang tubuh ilmu-ilmu keagamaan. Hal ini, menurut Amin Abdullah, menjadikan agama dan "kepentingannya" bercampur aduk. Demikian juga, ketumpang-tindihan antara dimensi sakraliatas dan profanitas dalam wilayah sosial-keberagamaan, terletak pada ruang praksis. Lebih lanjut, Amin menjelaskan bahwa hubungan antara sakral dan profan adalah sangat erat bahkan untuk kasus-kasus tertentu sangat campur aduk, tumpang tindih. ${ }^{48}$ Untuk itu, Amin menawarkan metodologi filsafat yang bersifat keilmuan, terbuka dan inklusif sebagai alternatif permasalahan tersebut.

Dalam kasus ini, penulis mencoba menganalogikan-untuk tidak mengatakan mengkritisi-kasus ketumpang-tindihan sakral dan profan melalui pendekatan Adams. Normatifitas dalam pendekatan Adams, meletakkan posisi Agama dalam wujud sakralnya karena pendekatan normatif berpijak pada dasar analisis yang memegang komitmen terhadap nilai religius. Berbeda dengan pendekatan deskriptis yang tanpa di dasari dengan nilai religius, pendekatan ini menerapkan pandangan-pandangan teoritik dan kekayaan metodologis dalam ilmu agama untuk menjelaskan dan menelaah berbagai macam wilayah kajian Agama sehingga dapat memberikan jawaban dari permasalahan yang muncul.

\footnotetext{
${ }^{46}$ Adams, "Islamic Religious Tradition", 34.

${ }^{47}$ Abdullah, Mencari Islam, 2.

48 Ibid., 5.
} 
Dengan adanya operasional konseptual dalam melakukan pendekatan terhadap agama, menjadikan agama bersifat profan (mu'amalah bain al-na>s). Adams membatasi hubungan keduanya dalam batas continuum (berkesatuan), sehingga ada korelasi jelas anatara normatif dan deskriptif maupun sakral dengan profan. Dengan artian bahwa pendekatan normatif menjaga Agama dalam wujud sakralnya sedangkan deskriptif, menelaah agama dengan metodologisnya. Dan keduanya merupakan satu kesatuan.

Kontribusi lain yang dihasilkan oleh Adams, sebagaiman diungkapkan oleh Andrew Rippin, melalui argumentasi dalam wilayah kajian Islam. Menurut Adams, penelitian terhadap al-Qur'an dapat dilakukan pada materi-materi pembentuk alQur'an, kronologi materi-materi yang tersusun dalam teks, sejarah teks, varian bacaan, hubungan al-Qur'an dengan literatur sebelumnya. Pendapat ini mengusik kesadaran John Wansbrough untuk melakukan studi lanjutan terhadap alQur'an. ${ }^{49}$

Menurut Amin Abdullah, Adams memiliki kontribusi dalam penerapan metodologi ilmu-ilmu sosial dalam ilmu-ilmu ke-Islaman. Kontribusi Adams ini juga mendapat dukungan yang kuat dari Richard C. Martin. Adams, sebagaimana dikutip Amin Abdullah, menegaskan simposium mengenai Islam dan sejarah Agama di Arizona State University telah memberikan perhatian besar pada aspekaspek khusu dalam tradisi keilmuan Islam dan menerapkan pandangan teoritik dan metodologi dalam ilmu agama untuk menjelaskan dan menelaah berbagai macam wilayah kajian keagamaan Islam. ${ }^{50}$

\section{KESIMPULAN}

Kajian tradisi keagamaan Islam yang dilakuakan Charles J. Adams, dimulai dengan memberikan pemahaman yang menyeluruh tentang apa yang dimaksud agama dan Islam. Pemakaian dua istilah dalam satu kajian, menjadikan Adams mengahadapi polemik besar. Polemik tersebut berkisar tentang bagaimana memahami dua istilah tersebut dan bagaimana penggunaannya.

Berangkat dari problematika tersebut, Adams kemudian memahami Islam dengan perspektif sejarah sebagai sebuah pengalaman yang terus berjalan dan

\footnotetext{
${ }^{49}$ Andrew Rippin, "Leterary Analysis of Qur'an, Tafsir and Sira; The Methologies of John Wansbrough", dalam Approaches to Islam in Religious Studies, 158.

${ }^{50}$ M. Amin Abdullah, Islamic Studies di Perguruan Tinggi: Pendekatan Integratif-Interkonektif (Yogyakarta:

Pustaka Pelajar, 2006), 33-34.
} 
ekpresi yang berdiri di atas perkembangan sejarah berdasarkan wahyu (massage) dan pengaruh Nabi. Sedangkan Agama dipahami oleh Adams dalam dua kutub yang berbeda. Di satu sisi, Agama sebagai hasil dari pengalaman manusia yang dapat diamati secara sosial dan historis, disisi lain, Agama adalah pengalaman manusia yang tak terdefinisikan karena merupakan bagian intern dari pengalaman itu sendiri.

Setalah dua terma ini telah jelas dan ditemukan batasan dalam penggunaannya, Adams kemudian mengajukan pendekatan dalam melakukan kajian terhadap Islam. Terdapat dua pendekatan yang dapat digunakan dalam melakukan studi terhadap Islam yang memiliki 11 pokok bahasan, pendekatan normatif-religius dan pendekatan deskriptif. Kedua pendekatan ini berada dalam satu kesatuan. Pendekatan normatif terdiri dari misionaris tradisional, apologetik dan irrenic. Sedangkan deskriptif terdiri dari filologis dan historis, ilmu sosial dan fenomenologis.

\section{DAFTAR PUSTAKA}

Abdullah, M. Amin, dkk. Mencari Islam: Studi Islam dengan Berbagai Pendekatan. Yogyakarta: Tiara Wacana Yogya, 2000.

Abdullah, M. Amin. Islamic Studies di Perguruan Tinggi: Pendekatan IntegratifInterkonektif. Yogyakarta: Pustaka Pelajar, 2006. Pelajar, 1996.

Studi Agama: Normativitas atau Historisitas. Yogyakarta: Pustaka

Adams, Charles J. "Islamic Religious Tradition" dalam The Study of the Middle East; Reasearch and Scholarship in the Humanities and the Social Science, ed. Leonard Binder. Canada: John Wiley \& Sons, 1979.

Connolly, Petter (ed.). Aneka Pendekatan Studi Agama, terj. Ninian Smart. Yogyakarta: LkiS, 2002.

Martin, Richard C. (ed.). Approaches to Islam in Religious Studies. USA: Arizona State University, 1985.

Nata, Abuddin. Metodologi Studi Islam. Jakarta: Rajawali Press, 2013.

Oxtoby, William K. Religious Diversity. New York: Crossroad, 1982.

Said, Edward W. Orientalisme: Menggugat Hegemoni Barat dan Menundukkan Timur sebagai Subjek, terj. Ahmad Fawaid. Yogyakarta: Pustaka Pelajar, 2010.

Smith, Wilfred Cantwell. Religious and Modernity. New York: The Crossroad, 1982. 